\title{
Inclusão educacional: estudo de caso de um aluno com dupla excepcionalidade
}

\author{
Waleska Karinne Soares Coutinho-Souto ${ }^{1}$ e Denise de Souza Fleith ${ }^{2}$ \\ Universidade de Brasília ${ }^{1,2}$ - Brasil
}

Escolas com orientação inclusiva são consideradas um meio eficaz de combate às atitudes discriminatórias. No caso dos alunos superdotados, tem-se observado um interesse pela realização de estudos envolvendo aqueles que apresentam, simultaneamente às habilidades superiores, dificuldades comportamentais, emocionais e de aprendizagem, fenômeno denominado dupla excepcionalidade. $\mathrm{O}$ objetivo deste estudo de caso foi analisar a inclusão educacional de um aluno superdotado com transtorno de Asperger a partir da perspectiva de gestores, professores, mãe e do próprio aluno. A inclusão educacional do aluno participante da pesquisa foi considerada um processo de natureza complexa e multidimensional por depender da participação de toda a comunidade escolar e da família. Verificou-se que o atendimento educacional especializado favoreceu sua inclusão educacional.

Palavras-chave: inclusão educacional, dupla excepcionalidade, superdotação, transtorno de Asperger

Educational inclusion: case study of a dual exceptional student

Schools with an inclusive perspective are considered an efficient tool to fight the discriminatory attitudes. In the case of gifted students, there has been an interest in carrying out studies involving those who present, simultaneously to the higher abilities, behavioral, emotional and learning difficulties, a phenomenon named dual exceptionality. The purpose of this case study was to analyze the educational inclusion of a gifted student with Asperger's disorder from the perspective of managers, teachers, mother and student himself. The educational inclusion of the participant was considered a complex and multidimensional process because it depends on the participation of the whole school community and family. It was verified that the specialized educational service favored the inclusion of the dual exceptional student. Keywords: educational inclusion, dual exceptionality, giftedness, Asperger disorder.

Inclusión educativa: estudio de caso de un alumno con doble excepcionalidad

Las escuelas con orientación inclusiva son consideradas como un medio eficaz de combate a actitudes discriminatorias. En el caso de los alumnos superdotados, se ha observado un interés por la realización de estudios involucrando a aquellos que presentan, simultánea-

1 Pedagoga, mestre em Processos de Desenvolvimento Humano e Saúde pela Universidade de Brasília. Endereço postal: QE 19 conjunto D casa 33, Guará II, Brasília - DF, Brasil. Contato: waleskacoutinho@bol.com.br ORCID: http://orcid.org/0000-0002-6996-2940

2 Psicóloga, Ph.D. em Psicologia Educacional pela University of Connecticut. Professora Titular do Instituto de Psicologia da Universidade de Brasília. Endereço postal: SQN 202, bloco H, apartamento 504, Asa Norte Brasília - DF. Contato: fleith@unb.br ORCID: https://orcid. org/0000-0001-7512-8023 
mente, las habilidades superiores y dificultades conductuales, emocionales y de aprendizaje, fenómeno denominado doble excepcionalidad. El objetivo de este estudio de caso fue analizar la inclusión educativa de un alumno superdotado con trastorno de Asperger desde la perspectiva de gestores, profesores, madre y del alumno. La inclusión del participante fue considerada un proceso de naturaleza compleja y multidimensional por depender de la participación de toda la comunidad escolar y de la familia. Se verificó que la atención educativa especializada favoreció su inclusión educativa.

Palabras clave: inclusión educativa, doble excepcionalidad, superdotación, trastorno de Asperger.

\section{Inclusion scolaire: étude de cas d'un élève ayant une double exception}

Les écoles à orientation inclusive sont considérées comme un moyen efficace de lutter contre les attitudes discriminatoires. Dans le cas des étudiantes surdoués, on s'intéresse aux études qui concernent ceux qui présentent, simultanément aux compétences supérieures, des difficultés comportementales, émotionnelles et d'apprentissage, un phénomène appelé la double exception. Le but de cette étude de cas était d'analyser l'inclusion éducative d'un étudiant surdoué avec le syndrome de Asperger du point de vue des gestionnaires, des enseignants, de la mère et de l'étudiant. L'inclusion scolaire du participant était considérée comme un processus complexe et multidimensionnel, car elle dépend de la participation de la communauté scolaire et de la famille. Il a été vérifié que le service éducatif spécialisé favorisait son inclusion scolaire.

Mots-clés: inclusion scolaire, double exception, surdouée, syndrome d'Asperger 
O contexto internacional de concretização de direitos humanos abrange um movimento que reforça a relevância da inclusão educacional dos alunos com necessidades especiais na rede regular de ensino (Assembleia Geral da Organização das Naçóes Unidas - ONU, 1948). Nessa perspectiva, estudos revelam que a consolidação das práticas inclusivas depende, fundamentalmente, da colaboração dos diversos atores envolvidos: gestores, professores, profissionais de apoio, funcionários, familiares, alunos e, em última instância, de toda a sociedade (Granemann \& Gricoli, 2011; Muega, 2016; Pimentel \& Nascimento, 2016). Pimentel e Nascimento (2016) sublinham que o envolvimento e a participação de toda a comunidade escolar são considerados fatores essenciais para o reconhecimento, a valorização e o respeito a todos os alunos, haja vista que apenas os aspectos legais não são suficientes para garantir o desenvolvimento e o fortalecimento da inclusão.

No que se relaciona especificamente ao papel desempenhado pelos gestores, Silva e Leme (2009) realçam que "a constituição de um ambiente propício à inclusão escolar depende de uma construção coletiva, na qual o diretor exercerá um papel decisivo" (p. 499). Na concepção de Kozleski et al. (2015), o posicionamento desse profissional pode ser considerado uma força motriz capaz de impulsionar o esforço de toda a equipe de trabalho em prol da educação inclusiva. Já com relação à participação dos professores, observa-se nas pesquisas que há um forte consenso sobre a importância da formação docente como um dos principais pilares de sustentação das práticas pedagógicas inclusivas (Song, 2016; Teixeira et al., 2016; Zagona et al., 2017).

Com respeito ao envolvimento dos pais, Delou (2007) esclarece que "toda criança possui potencialidades, capacidades e talentos inscritos nas experiências humanas, que serão desenvolvidos conforme as oportunidades que lhes sejam oferecidas inicialmente pela família" (p. 131). Consoante a autora, em tempos de políticas públicas inclusivas, torna-se relevante esclarecer a maneira como as famílias apoiarão o adequado desenvolvimento de seus filhos em parceria com a escola, o que pressupóe que "os pais devem ter confiança na capacidade das insti- 
tuições escolares educarem alunos com e sem necessidades educacionais especiais em conjunto" (Barbosa et al., 2007, p. 448).

Nas últimas duas décadas, tem-se observado um interesse crescente pela realização de estudos envolvendo superdotados que apresentam, simultaneamente às habilidades superiores, dificuldades comportamentais, emocionais e de aprendizagem. Na literatura, a sobreposição dessas características, aparentemente antagônicas, passou a ser denominada de dupla excepcionalidade (Arizaga, Conejeros-Solar, Rodríguez, \& Solís, 2016; Bianco et al., 2009; Delou, 2013; Foley-Nicpon et al., 2011; Guimarães \& Alencar, 2012; Ourofino, 2007; Vilarinho-Rezende et al., 2016; Webb et al., 2007). De acordo com Ourofino (2007), estudiosos da área de superdotação passaram a demonstrar interesse em compreender os processos diferenciados de desenvolvimento dos alunos com dupla excepcionalidade pelo fato da combinação entre alta inteligência, múltiplas potencialidades e possíveis distúrbios comportamentais e/ou emocionais constituir um achado, muitas vezes, paradoxal nas pesquisas com superdotados.

De maneira geral, as investigaçóes abordam a questão da dupla condição envolvendo a superdotação em conjunto com outras subpopulaçóes especiais, ou seja, transtornos comportamentais e emocionais, transtorno de déficit de atenção e hiperatividade, dificuldades visuais e auditivas, dificuldades de aprendizagem, transtorno do espectro autista, transtorno de Asperger (Arizaga et al., 2016; Besnoy et al., 2015; Foley-Nicpon et al., 2013; Ng et al., 2016; Park et al., 2018; Rubenstein et al., 2015; Willard-Holt et al., 2013).

De acordo com Neihart (2000), o transtorno de Asperger foi descrito pela primeira vez pelo médico austríaco Hans Asperger em 1944. Ele foi considerado pelo pesquisador como uma desordem da personalidade caracterizada por fala de conteúdo pedante, prejuízo nas interaçôes sociais, excelente pensamento lógico abstrato, áreas de interesse isoladas, comportamento repetitivo e estereotipado e ignorância das demandas ambientais; além de ser mais comum em meninos do que em meninas. Recentemente, o Manual Diagnóstico e Estatístico de Transtornos Mentais 5a Edição (DSM - 5, American Psychiatric 
Association - APA, 2014) e o novo Código Internacional de Doenças (CID - 11, World Health Organization - WHO, 2018) incluíram o transtorno de Asperger no denominado transtorno do espectro autista (TEA), com base em dois domínios centrais: (a) déficit na comunicação social e interação social e (b) padróes repetitivos e restritos de comportamento, interesses e atividades. Entretanto, foi salientado em ambos os documentos que os indivíduos com Asperger não apresentam comprometimentos significativos de natureza linguística ou intelectual.

Para Guimarães e Alencar (2012), o aspecto que talvez mais diferencie os superdotados daqueles com transtorno de Asperger seja a falta de compreensão dos últimos com relação aos sentimentos, necessidades, percepçóes e interesses das outras pessoas. De forma geral, os indivíduos com Asperger podem, por exemplo, falar incansavelmente sobre seu tema de preferência sem perceber que muitas vezes o interlocutor não está interessado no assunto ou até mesmo interromper abruptamente a conversa particular de alguém sem notar a inconveniência de tal atitude. Falta-lhes, portanto, uma compreensão adequada da perspectiva do outro, bem como das regras e costumes de convivência social. Esse tipo de comportamento não é comumente descrito entre os superdotados, haja vista que eles compreendem outros pontos de vista e são empáticos seus relacionamentos sociais.

Os estudos empíricos que tratam estritamente da dupla excepcionalidade superdotação/transtorno de Asperger ainda são escassos tanto no contexto internacional (Horn, 2012; Jonhson, 2010; Lindquist, 2006; Wright, 2016) quanto nacional (Delou, 2013; Guimarães, 2009; Silveira, 2014; Vilarinho-Rezende et al., 2016). No contexto norte-americano, Wright (2016) realizou um estudo, com 242 professores de educação infantil, com o objetivo de analisar como os diferentes tipos de certificação de pós-graduação (educação geral, superdotação e educação especial) afetam o conhecimento dos professores da primeira infância sobre as características do aluno com transtorno de Asperger e/ou superdotação. A análise dos dados indicou que os professores que possuem certificação sobre superdotação e/ou educação especial demonstram maior conhecimento sobre as características do aluno com 
dupla excepcionalidade em comparação com os demais professores de educação geral. Estudo de caso empreendido por Lindquist (2006), também nos Estados Unidos, igualmente evidenciou a importância do treinamento de professores para identificar alunos com características de superdotação/transtorno de Asperger em suas salas de aula. Para a autora, tornou-se evidente que, com apoio adequado, os alunos com dupla excepcionalidade são capazes de realizar enormes progressos em sua capacidade de gerenciamento de ambas as condiçóes.

No Brasil, pesquisas empíricas acerca da dupla condição superdotação/transtorno de Asperger têm sido baseados na abordagem qualitativa de estudo de caso único (Delou, 2013; Guimarães, 2009; Silveira, 2014; Vilarinho-Rezende et al., 2016). Guimarães (2009) destacou em seu estudo que se o estudante com dupla excepcionalidade for atendido em suas necessidades educativas especiais - com inclusão na sala de aula regular, currículo flexível e participaçáo em programas para alunos com altas habilidades/superdotaçáo - ele terá maiores chances de obter sucesso em sua trajetória escolar. Em contrapartida, diferentemente de Guimarães (2009), Silveira (2014) constatou em sua pesquisa que apesar do estudante superdotado com transtorno de Asperger apresentar altas habilidades em diversos domínios do conhecimento, a escola dificultou seu processo de aprendizagem por deixar de oferecer-lhe atividades de diferenciação curricular e de aceleração de conteúdo. Para a autora, tal medida pedagógica desencadeou um aumento em seus comportamentos inadequados e de sua rejeição por parte de colegas e professores, já que as suas dificuldades foram mais valorizadas no contexto escolar do que suas potencialidades.

No que diz respeito aos estudos com adultos, Delou (2013) propôs uma pesquisa com o intuito de promover a inclusão educacional, no ambiente universitário, de um jovem com dupla excepcionalidade, superdotação/transtorno de Asperger, a partir de uma metodologia de tutoria pedagógica à comunidade acadêmica. Os resultados da pesquisa mostraram que a metodologia adotada promoveu o sucesso escolar do aluno, visto que ele conseguiu concluir o curso com êxito e também apresentou progressos em seu processo de socializaçáo. Depreendeu-se 
que a tutoria pedagógica estimulou a criação de novas práticas de ensino destinadas a promover a inclusão de pessoas com características diferenciadas na universidade. Já o estudo de caso conduzido por Johnson (2010), com um adulto americano superdotado com transtorno de Asperger, evidenciou que a identificação precoce e a adoção de estratégias de ensino diferenciadas revelaram-se como importantes ferramentas educativas de intervenção para a promoção do sucesso desses indivíduos. Percebeu-se que os estudantes com dupla excepcionalidade necessitam de intervençôes educacionais que apresentem interconectividade entre ambas as condiçóes, além de professores adequadamente qualificados, pois o não atendimento às suas necessidades pode ocasionar prejuízos que impeçam o desenvolvimento de seu talento.

Consoante Baum (2009), Bianco et al. (2009) e Webb et al. (2007), a escola deveria estimular os alunos com dupla excepcionalidade a utilizar suas características fortes para compensar suas possíveis fragilidades, haja vista ser fundamental que o atendimento a esses alunos esteja fundamentado na promoção de suas potencialidades e na superação de suas dificuldades. Nesse sentido, a construção de uma escola verdadeiramente inclusiva depende de um currículo intelectualmente desafiador que leve em consideração os interesses individuais, para que cada aluno, em seu próprio ritmo, seja capaz de atingir o melhor desenvolvimento possível de seus talentos e habilidades. Por isso, a inclusão de alunos com tais singularidades necessita da organização de uma rede de apoio sistematizada que lhes ofereça suporte acadêmico, social e emocional a partir da colaboração e do comprometimento de todos os envolvidos nesse processo: gestores, professores, especialistas, pais, colegas e dos próprios estudantes. Quando os alunos com dupla excepcionalidade recebem apoio e são expostos a um ambiente de aprendizagem estimulante e encorajador, embasado nas adaptaçóes curriculares pertinentes a seu caso particular, eles tendem a obter sucesso e a sentirem-se efetivamente incluídos e aceitos no contexto escolar (Bianco et al., 2009).

Observa-se, portanto, a importância de mais estudos empíricos que investiguem a inclusão educacional dos alunos com dupla excepcionalidade na classe comum do ensino regular e que examinem os 
fatores que favorecem ou dificultam a consolidação de tal prática pedagógica no ambiente escolar. É neste contexto que se propôs o presente estudo de caso com o objetivo de analisar o processo de inclusão educacional de um aluno superdotado com transtorno de Asperger no ensino fundamental a partir da perspectiva dos diversos atores envolvidos: gestores, professores, mãe e o próprio aluno. Espera-se que este estudo enriqueça a literatura sobre o tema e sirva de subsídio para promover a inclusão educacional de alunos com dupla excepcionalidade.

\section{Método}

\section{Participantes}

Foi selecionado para participar deste estudo de caso único um aluno do gênero masculino, com 11 anos de idade e com características de dupla excepcionalidade: superdotação e transtorno de Asperger, aqui identificado com as iniciais G.D. Em 2018, ano da coleta de dados, ele estava matriculado em uma classe comum do ensino regular de $7^{\circ}$ ano do ensino fundamental de uma escola pública (CEF A) e também frequentava no contraturno, em uma instituição de ensino vizinha (CEF B), uma das salas de recursos do atendimento educacional especializado aos alunos com altas habilidades/superdotação da Secretaria de Estado de Educação do Distrito Federal (SEEDF), localizada na região centro-oeste do Brasil. Ele é filho único e, desde o seu nascimento, convive apenas com adultos em sua residência: sua mãe e duas tias maternas. O pai é militar e fornece apoio financeiro ao filho por meio de pensão alimentícia depositada mensalmente. De acordo com a mãe, o contato entre o pai e o filho é esporádico e pouco frequente. A escolha por esse participante foi de conveniência.

A identificação da superdotação aconteceu aos 5 anos de idade pela psicóloga da sala de recursos para atendimento educacional especializado aos alunos com altas habilidades/superdotação, após o aluno ter sido encaminhado para avaliação por sua professora do primeiro período da educaçáo infantil. Já o transtorno de Asperger foi reco- 
nhecido por médica neurologista quando o aluno tinha 10 anos de idade e estava cursando o $5^{\circ}$ ano do ensino fundamental. Durante toda a sua trajetória escolar, o aluno frequentou apenas instituiçóes públicas de ensino e sempre esteve incluído em classes comuns do ensino regular. Além disso, desde o primeiro período da educação infantil até o momento da coleta de dados, ele foi atendido ininterruptamente pela sala de recursos de altas habilidades/superdotação, o que totaliza um período de 8 anos consecutivos. Suas áreas de interesse identificadas pelos profissionais da sala de recursos são língua estrangeira (inglês e espanhol), música e cinema.

Contribuíram para elucidação do caso:

- A mãe do aluno: trata-se de uma mulher solteira de 53 anos de idade, com formação a nível de ensino médio em magistério (antigo Curso Normal) e que trabalha como profissional liberal (manicure) em sua própria residência.

- A gestora da escola regular: reporta-se a uma mulher com 51 anos de idade, graduada em Matemática, com 29 anos de docência e com um ano de experiência em gestão escolar.

- Dois professores da classe comum do ensino regular: (a) professora do aluno no primeiro período da educação infantil - mulher com 48 anos de idade, com 30 anos de docência, com formação a nível de ensino médio em magistério (antigo Curso Normal), graduada em História e com pós-graduação lato sensu em psicopedagogia clínica; e (b) professor atual do aluno de Educação Artística: homem com 57 anos de idade, com 40 anos de docência, graduado em História e Artes Plásticas e com pós-graduação lato sensu em cultura e história africana e afro-brasileira. Durante sua trajetória profissional, o professor atuou por 6 meses na sala de recursos para atendimento educacional especializado aos alunos com altas habilidades/superdotaçáo na área de talento artístico.

- Uma professora da sala de recursos para atendimento educacional especializado aos alunos com altas habilidades/superdotação: refere-se a uma mulher com 37 anos de idade, com nove anos de 
magistério (dos quais quatro no atendimento educacional especializado em altas habilidades/superdotação), com formação a nível de graduação em Pedagogia e com pós-graduação lato sensu em atendimento educacional especializado para o atendimento a alunos com altas habilidades/superdotação e também em psicopedagogia com ênfase em educação especial.

\section{Mediçâo}

Foram realizadas seis entrevistas semiestruturadas, todas elas gravadas em áudio, com a devida autorização dos entrevistados e, posteriormente, transcritas na íntegra pelas pesquisadoras. Primeiramente, foi conduzida uma entrevista com a mãe, com duração aproximada de 90 minutos, na residência da família. Os tópicos abordados foram: (a) descrever a trajetória escolar do filho desde que ingressou na escola; (b) examinar como aconteceu o processo de identificação da dupla excepcionalidade no filho; (c) explorar os principais desafios percebidos pela mãe na inclusão educacional do filho superdotado com transtorno de Asperger; (d) verificar os aspectos que contribuíram para o processo de inclusão educacional do aluno, de acordo com a mãe; e (e) identificar a relevância conferida pela mãe ao atendimento educacional especializado oferecido na sala de recursos de altas habilidades/superdotação para potencializar a aprendizagem, o desenvolvimento e a inclusão educacional do filho. Após o consentimento da mãe, foi proposta uma entrevista semiestruturada com o aluno com duração média de 60 minutos, em ambiente reservado da sala de recursos, com as seguintes intenções: (a) identificar seus talentos e áreas de interesse, (b) reconhecer o que desperta seu interesse e motivação no contexto escolar, (c) identificar as possíveis dificuldades enfrentadas por ele na escola, (d) descrever seu relacionamento com colegas e professores, e (e) analisar a importância atribuída por ele ao trabalho desenvolvido na sala de recursos para o desenvolvimento de seu talento.

Posteriormente, foram entrevistados a gestora da escola regular, a professora do aluno do primeiro período da educaçáo infantil e os atuais professores do aluno de Educaçáo Artística e da sala de recursos 
para atendimento educacional especializado aos alunos com altas habilidades/superdotação. Todas as entrevistas foram realizadas em ambiente reservado no contexto escolar e tiveram duração aproximada de 35 minutos cada uma delas. A entrevista semiestruturada com a gestora da escola regular foi proposta com os seguintes objetivos: (a) identificar as estratégias utilizas pela escola para promover a inclusão dos alunos com necessidades especiais, (b) explorar os principais desafios e avanços percebidos pelo gestor no processo de inclusão educacional dos alunos com necessidades especiais, (c) descrever as açóes realizadas pela escola para promover a formação continuada dos professores na perspectiva inclusiva, e (d) reconhecer a importância atribuída pelo gestor ao atendimento educacional especializado oferecido na sala de recursos para potencializar a aprendizagem e o desenvolvimento dos alunos com necessidades especiais. Já as entrevistas semiestruturadas com os professores foram realizadas com as seguintes finalidades: (a) identificar as estratégias pedagógicas utilizas pelos professores para promover a inclusão do aluno com dupla excepcionalidade, (b) explorar os principais desafios e avanços percebidos pelos professores no processo de inclusão educacional do aluno superdotado com transtorno de Asperger, (c) verificar os aspectos que contribuíram para o processo de inclusão educacional do aluno superdotado com transtorno de Asperger, e (d) examinar a relevância conferida pelos professores ao atendimento educacional especializado oferecido na sala de recursos de altas habilidades/superdotaçáo para potencializar a aprendizagem e o desenvolvimento do aluno dupla excepcionalidade.

Além das entrevistas, foi promovida uma análise documental da política pública de educação inclusiva da SEEDF e da trajetória escolar do aluno. Os documentos analisados foram: orientação pedagógica da SEEDF para a educação especial (SEEDF, 2010), referenciais da SEEDF para atuação do serviço especializado de apoio à aprendizagem (SEEDF, 2014), ficha de indicação do aluno para atendimento educacional especializado na sala de recursos de altas habilidades/ superdotação, relatórios dos professores, questionário de anamnese para a família, avaliação psicológica do serviço especializado de apoio à 
aprendizagem e relatórios médicos. É importante ressaltar que a análise documental referente à vida escolar e aos registros diagnósticos do aluno, previamente autorizada pela mãe, foi produzida em ambiente reservado da sala de recursos e da escola regular, totalizando cerca de 5 horas de duração.

Também foram realizadas observaçôes diretas do aluno na classe comum do ensino regular e na sala de recursos para atendimento educacional especializado aos alunos com altas habilidades/superdotação considerando: (a) a interação do aluno com colegas e professores, (b) as estratégias pedagógicas utilizadas pelos professores para promover o desenvolvimento do aluno, e (c) as atividades realizadas pelo aluno que mais despertam seu interesse e motivação, bem como aquelas que menos o motivam. As observaçóes aconteceram no decorrer de cinco aulas (três na sala de recursos altas habilidades/superdotação e duas na classe comum da disciplina de educação artística), tendo cada uma delas duração aproximada de 100 minutos. Todas elas foram devidamente autorizadas pelos professores participantes da pesquisa.

\section{Procedimentos}

Inicialmente, foi encaminhada uma carta de apresentação da pesquisa a uma das Unidades Regionais de Educação Básica (UNIEB) da SEEDF com o intuito de requerer autorização para efetivação do estudo em suas unidades escolares. Após aprovação da realização da pesquisa pela UNIEB, a primeira autora do estudo dirigiu-se à sala de recursos de altas habilidades/superdotação para verificar com os profissionais responsáveis pelo atendimento um possível aluno com características de dupla excepcionalidade para participar do estudo. Foi agendado pela professora itinerante um encontro individual entre a primeira autora e cada um dos possíveis participantes (mãe, diretora da escola regular e professores). Em cada um desses encontros, foram lidos para os participantes o Termo de Consentimento Livre e Esclarecido (TCLE) e expostos o objetivo do estudo. Foi assegurado a todos eles que a participação na pesquisa não lhes acarretaria nenhum prejuízo de qualquer natureza e que seria mantido sigilo absoluto sobre quaisquer 
informaçóes que porventura pudesse identificá-los. Além disso, foi esclarecido a cada um que eles possuíam total liberdade para recursar-se a participar, retirar o consentimento ou interromper a participação a qualquer momento. Todos eles concordaram em colaborar com o estudo e assinaram o (TCLE). A mãe autorizou a participação do filho na pesquisa.

\section{Análise de Dados}

Os dados foram analisados mediante a triangulação dos dados obtidos a partir das diferentes fontes utilizadas (entrevista semiestruturada, observação e análise documental), de modo a identificar os fatores que contribuem ou dificultam a inclusão do aluno com dupla excepcionalidade na classe comum do ensino regular, bem como o papel desempenhado pela sala de recursos de altas habilidades/superdotação no favorecimento desse processo. $\mathrm{O}$ método de análise de dados empregado foi a análise de conteúdo qualitativa. De acordo com Bardin (1977), a análise de conteúdo é um conjunto de instrumentos metodológicos que se aplicam a discursos extremamente diversificados. Seu objetivo consiste em possibilitar o desencadeamento de inferências específicas ou interpretaçóes casuais sobre um determinado aspecto da orientação comportamental do locutor nos contextos comunicativos.

\section{Resultados}

\section{Fatores que contribuíram para a inclusáo educacional do aluno com dupla excepcionalidade}

Com relação aos fatores que contribuem para o processo de inclusão do aluno superdotado com transtorno de Asperger na escola regular, destacaram-se os seguintes aspectos: (a) a política pública da SEEDF de atendimento ao aluno com necessidades especiais, (b) o apoio da gestão escolar à inclusão dos alunos com necessidades especiais, (c) a presença do atendimento educacional especializado na escola regular, (d) a formação e o tempo de experiência profissional dos professores, (e) a 
identificação precoce das características de superdotação do aluno no contexto familiar e escolar, (f) a valorização da habilidade cognitiva do aluno pela família e pela escola, $(\mathrm{g})$ o relacionamento positivo entre o aluno e seus professores, (h) a participação ativa da mãe na vida escolar do aluno, (i) o apoio da mãe às necessidades emocionais do filho, e (j) o autoconceito positivo do aluno.

Politica pública da SEEDF de atendimento ao aluno com necessidades especiais. A partir de 2008, a SEEDF, respaldada na Política Nacional de Educação Especial na Perspectiva da Educação Inclusiva (Ministério da Educação, 2008), ampliou significativamente o quantitativo de salas de recursos destinadas a oferecer atendimento educacional especializado aos alunos com necessidades especiais (deficiência física, intelectual, sensorial, transtorno global do desenvolvimento e altas habilidades/ superdotação). Em 2014, alargou mais uma vez o atendimento ofertado a esse público por meio da criação das salas de apoio à aprendizagem, as quais foram destinadas a prestar suporte aos alunos com transtornos funcionais específicos: transtorno de déficit de atenção e hiperatividade, dislexia, transtorno de conduta, transtorno opositor desafiador, distúrbio do processamento auditivo central, dentre outros (SEEDF, 2014).

No que se refere especificamente ao atendimento educacional especializado destinado aos alunos com altas habilidades/superdotação, é importante ressaltar que a SEEDF ocupa um papel de pioneirismo no contexto brasileiro, haja vista que desde 1976, isto é, há 42 anos, instituiu políticas públicas de apoio ao desenvolvimento do estudante talentoso. Atualmente, de maneira geral, cada uma das salas de recursos para atendimento ao aluno com altas habilidades/superdotação da rede conta com o apoio de uma equipe multidisciplinar composta por profissionais devidamente capacitados (psicólogos, itinerantes, professores com formação na área de pedagogia, códigos e linguagens, ciências humanas, ciências da natureza e/ou matemática e suas tecnologias) para prestar assistência a esses alunos nas áreas social, educacional e emocional (SEEDF, 2010).

Com relação à análise documental da trajetória escolar do aluno participante deste estudo de caso, foi possível constatar que a política 
pública de educação inclusiva da SEEDF favoreceu significativamente esse estudante, dado que desde o início de sua vida escolar, no primeiro período da educação infantil, ele sempre teve a oportunidade de frequentar exclusivamente turmas inclusivas da rede pública de ensino. Além disso, desde os 4 anos de idade até o momento da realização da pesquisa, o que totaliza um período de oito anos, esse aluno foi acolhido continuamente pelo atendimento educacional especializado aos alunos com altas habilidades/superdotação, o que, seguramente, contribuiu para seu sucesso acadêmico, para seu melhor ajustamento no contexto escolar e para a potencialização de seu desenvolvimento cognitivo, social e emocional.

Conforme os relatos dos participantes deste estudo, realmente a SEEDF fomenta em sua rede de ensino a adoção de políticas públicas que favorecem a inclusáo educacional dos alunos com necessidades especiais, pois existiu convergência entre o que está posto nos documentos norteadores da SEEDF e a percepção dos participantes sobre a inclusão no contexto escolar pesquisado. Os relatos revelam ação da escola regular, em que o aluno está matriculado, em prol da inclusão escolar, além de uma cultura e equipe escolar que acolhem e atendem os alunos com necessidades especiais.

Nossa escola começou a adotar uma proposta pedagógica inclusiva desde 2007. Acho que, oficialmente, isso aconteceu em 2008 com a abertura da sala de recursos. Hoje, nós temos, aproximadamente, 75 alunos com necessidades especiais matriculados na escola. Eu percebo que a inclusão dos alunos com necessidades especiais a cada ano melhora porque a SEEDF até já incluiu uma semana de educação e acessibilidade para as pessoas que são portadoras de qualquer transtorno no calendário. Essas açôes acontecem ao longo do ano. Mas, em especial nessa semana se valoriza até para se tornar público e chamar a comunidade para a responsabilidade que todos têm. (Gestora da escola regular)

Durante as observaçóes realizadas na classe comum do ensino regular (CEF A) e na sala de recursos para atendimento educacional especializado aos alunos com altas habilidades/superdotação (CEF B) 
foi possível perceber que ambas as escolas contavam, no momento da pesquisa, com o auxílio de vários profissionais especializados para apoio à inclusão dos alunos com necessidades especiais, tais como: (a) orientadores educacionais; (b) psicólogos; (c) pedagogos; (d) professores especializados na sala de recursos generalista, na sala de recursos de altas habilidades/superdotação e na sala de apoio; e (e) monitores e educadores sociais.

Apoio da gestão escolar à inclusão dos alunos com necessidades especiais. Conforme os relatos dos participantes, o apoio da gestáo foi evidenciado como um dos fatores que contribuem para o processo de inclusão dos alunos com necessidades especiais na escola regular, favorecendo, também, o desenvolvimento do aluno superdotado com transtorno de Asperger participante deste estudo.

A direção da escola tem aquele discurso que a gente vê na coordenação: a nossa escola é inclusiva. (Professor atual do aluno de educação artística)

A diretora é muito gente boa, muito receptiva. Ela é uma boa diretora. Ela é aberta. (Mãe)

Presença do atendimento educacional especializado na escola regular. De acordo com os participantes, a presença do atendimento educacional especializado favorece a inclusão dos alunos com necessidades especiais na escola regular, pois, de maneira geral, o trabalho realizado pelos profissionais da sala de recursos é de fundamental importância para o desenvolvimento cognitivo, social e emocional desses alunos, inclusive do aluno com dupla excepcionalidade participante deste estudo de caso.

A importância desse trabalho é a criança sendo vista com as particularidades dela, sendo atendida naquilo que ela tem limitaçáo e naquilo que ela precisa ser desenvolvida. (Professora do aluno no primeiro período da educaçáo infantil)

Assim, o que eu acho da sala de recursos: eu acho um lugar legal. E é bem, assim, receptivo porque ajuda alguns alunos a também desenvolverem um pouquinho da mente deles. (Aluno) 
Formação e o tempo de experiência profissional dos professores. $\mathrm{O}$ processo de formação inicial e continuada dos professores foi descrito pelos participantes como imprescindível ao favorecimento da inclusão dos alunos com necessidades especiais, inclusive do aluno com dupla excepcionalidade. No que se refere à formaçáo inicial, todos os professores que participaram da pesquisa tinham nível superior completo e pós-graduação lato sensu, um deles com duas pós-graduaçóes na área de educação especial.

Eu sou formada em pedagogia pela Universidade de Brasília (UnB) e já fiz especialização em psicopedagogia com ênfase no ensino especial e também fiz outra especialização para trabalhar com atendimento educacional especializado exigida para se trabalhar com altas habilidades. (Professora atual do aluno da sala de recursos para atendimento educacional especializado aos alunos com altas habilidades/superdotação)

No que diz respeito ao processo de formaçáo continuada, tanto a gestora quanto os professores relataram que a SEEDF ou a própria escola em que trabalham promovem cursos de formação continuada na perspectiva inclusiva.

$\mathrm{Na}$ parte pedagógica, a gente sempre faz formação coletiva com os professores buscando estratégias diferentes para que esses alunos possam aprender e para garantir essas aprendizagens. Existem cursos na EAPE (Centro de Aperfeiçoamento dos Profissionais de Educação da SEEDF) e palestras, mas a SEEDF também oferece profissionais que vão até a escola para estar trabalhando essas questôes com os professores. (Gestora da escola regular)

Tem muitos cursos da EAPE, mas a gente só tem esses cursos que a escola mesmo dá. Nessa escola, teve, no início do no ano, uma formação e em outra escola que eu trabalhei também teve uma formação, mas dentro da própria coordenaçáo. Foi um curso geral de como trabalhar a inclusão educacional. (Professor atual do aluno de educação artística) 
Vale destacar que, durante o período de observação realizado no CEF A, foi possível acompanhar, no horário de coordenaçáo pedagógica, um momento de formaçáo continuada oferecido pela psicóloga da sala de apoio à aprendizagem aos professores da classe comum da escola. Nesse encontro, com duração de 2 horas aproximadamente, a psicóloga realizou uma palestra sobre os seguintes transtornos funcionais específicos: distúrbio do processamento auditivo central, dislexia, disortografia, disgrafia, dislalia, discalculia, transtorno de déficit de atenção e hiperatividade, transtorno opositor desafiador e transtorno de conduta. Mais uma vez, foi possível perceber a existência de convergência entre a fala da gestora e do professor de educação artística e as açôes de capacitação ofertadas pela escola no que concerne à temática da educação inclusiva no CEF A. Além disso, de forma geral, todos os professores participantes do estudo tinham uma larga experiência profissional na educaçáo básica, o que contribuiu para implementação bem-sucedida de práticas de inclusão escolar.

Eu já estou há 26 anos na SEEDF e tenho quatro anos de escola particular. Entáo, 30 anos de sala de aula. Todos como regente. Agora mesmo eu recebi uma criança com suspeita de autismo. Eu falei com os pais e eles já levaram o filho em um neurologista. (Professora do aluno no primeiro período da educação infantil)

\section{Identificação precoce das características de superdotação do aluno no} contexto familiar e escolar. De acordo com a entrevista realizada com a mãe, seu filho apresentou, desde muito pequeno, comportamentos precoces no contexto familiar, principalmente, no que diz respeito a: (a) aquisição da linguagem oral, (b) aprendizagem da leitura, e (c) interesse por músicas e filmes.

Em todos os lugares que eu passava, ele surpreendia e chamava atenção por essa questáo de falar muito bem e de falar palavras que não eram comuns para criança. Ele aprendeu a ler sozinho. Depois, ele foi para a área de cinema. Qual foi o período do cinema preto e branco, quando foi o primeiro cinema colorido, os grandes diretores do cinema. Quando ele pegava um filme ou um desenho, ele queria 
saber o tema musical, quem tinha produzido, quem tinha trabalhado no filme. (Mãe)

Entretanto, formalmente, a identificação da superdotação do aluno aconteceu apenas aos 5 anos de idade pela psicóloga da sala de recursos para atendimento educacional especializado aos alunos com altas habilidades/superdotaçáo, após encaminhamento realizado por sua professora do primeiro período da educação infantil. No decorrer da entrevista realizada com a professora, ela mencionou que percebia que o aluno apresentava comportamentos diferenciados em comparação com as demais crianças da turma e que, por esse motivo, decidiu indicá-lo para a sala de recursos de altas habilidades.

Essa questão do interesse dele pelos filmes, nomes, autores e ediçóes. Isso já era uma habilidade que eu percebi que não era uma habilidade nata das crianças da educação infantil. A questão da memória dele que era espetacular. Se ele lesse um texto agora, ou qualquer coisa, ele saberia falar de cor em segundos. Quando eu comparava com os outros alunos da turma, ele estava há anos luz nesse aspecto. A intervençáo precoce é tudo. (Professora do aluno no primeiro período da educação infantil)

Consoante a análise documental empreendida acerca da trajetória escolar do aluno, após o encaminhamento realizado pela professora, a psicóloga da sala de recursos de altas habilidades/superdotação concluiu em seu relatório que, naquele momento, o estudante evidenciava características de precocidade no desenvolvimento acadêmico, com bom nível de pensamento original e forte motivação pelos desafios no processo ensino-aprendizagem. Para a psicóloga, ele apresentava habilidade cognitiva acima da média, aprendizagem rápida, excelente memória, boa expressão verbal, vocabulário avançado para a idade, interesses diversificados e agilidade para produzir ideias o que, certamente, confirmou os relatos anteriormente descritos tanto pela mãe quanto pela professora.

Valorização da habilidade cognitiva do aluno pela família e pela escola. De forma unânime, todos os participantes da pesquisa (gestora, 
professores, mãe e inclusive o próprio aluno) demonstraram valorizar a habilidade cognitiva acima da média apresentada pelo estudante.

Excepcional. Ele é muito inteligente. (Professora atual do aluno da sala de recursos para atendimento educacional especializado aos alunos com altas habilidades/superdotaçáo)

Ele é muito inteligente. Ele tem tirado boas notas. Ele passou com 10 no primeiro bimestre. Ele tem uma capacidade de abstração de conhecimentos muito rápida, muito ágil. (Professor atual do aluno de educação artística)

Sou uma pessoa inteligente. Uma pessoa que tem habilidades acima da média e inteligência acima da média. (Aluno)

Relacionamento positivo entre o aluno e seus professores. Nas entrevistas realizadas tanto com a mãe quanto com o aluno, foi possível constatar que, na percepção de ambos, a relação entre o aluno e seus professores é positiva. Ele referiu-se aos professores como legais, carinhosos, atenciosos, calmos, receptivos, divertidos ou espontâneos.

Hoje ele tem vínculo com os professores e ele avalia os professores. Ele gostou muito do professor do ano passado de Português. O professor tocava violáo e chamava ele para interagir, para cantar. Ele gosta muito do professor de Artes de agora e do de Inglês. (Mãe)

Bom, assim, relação com professor sempre foi um negócio muito forte comigo. A minha relação com os professores é uma relação boa. Ainda mais que eu sou um aluno exemplar e que faz as coisas direitinho. Eles percebem e têm um carinho especial por mim. (Aluno)

Participação ativa da máe na vida escolar do aluno. De modo consensual, a participação da mãe na vida escolar do filho foi percebida por todos os professores e por ela mesma como um dos fatores que favorecem a inclusão educacional do aluno.

A mãe é presente em tudo. Ela é presente. Ela é solicita. Ela é muito aberta, se eu precisar conversar com ela eu converso. (Professora 
atual do aluno da sala de recursos para atendimento educacional especializado aos alunos com altas habilidades/superdotaçáo)

Tudo o que eles querem que o G.D. faça na escola eu dou apoio e incentivo. Em trabalhos que ele vai apresentar, eu incentivo. Eu faço trabalho com ele. Eu dou sugestóes para ele. Eu pergunto para os professores como que o G.D. está. Eu estou sempre lá dentro da escola. A minha presença tem influência. A parceria entre a família e a escola é fundamental. (Mãe)

Apoio da mãe às necessidades emocionais do filho. No decorrer das entrevistas conduzidas com a mãe e com o aluno, ficou evidente que a inclusão dele no ambiente escolar é favorecida pelo apoio emocional recebido de sua mãe no contexto familiar.

Ele gosta de contar o que acontece na escola. Eu falo para o G.D.: "Tudo o que acontece na escola você tem que me dizer". E eu canso de dizer para ele: "Você não precisa tirar 10. Você só precisa passar de ano. Você não é obrigado a tirar 10 sempre”. (Mãe)

A minha mãe ela não só é como todas as mães, mas ela é também um pouquinho mais. Ela é receptiva. Ela sempre diz: "quando você tiver algum problema fala comigo, eu vou entender, compreender e te ajudar". E ela realmente faz isso. Tem vezes em que eu falo algumas coisas que estão acontecendo, algum problema que está acontecendo e, geralmente, nessas situaçôes ela é bem receptiva. (Aluno)

Autoconceito positivo do aluno. Durante a entrevista realizada com o aluno, foi possível perceber que ele possui uma imagem positiva de si mesmo e de suas habilidades, reconhecendo inclusive que, como qualquer ser humano, também possui algumas limitações.

Bom, basicamente, eu sou uma pessoa, mesmo sendo uma pessoa superdotada. Não vejo o problema em não me aceitar. Sou uma pessoa inteligente, boa, receptiva, graciosa e um pouco solidário. E no caso, uma pessoa que tem habilidades acima da média e inteligência acima da média, mas não quer dizer que eu seja só isso. Temos nossas capacidades, ensinamentos, temos nossos dons, temos nossas 
qualidades, temos nossos erros, temos nossas especialidades, temos nossas dificuldades em certas coisas, temos tudo isso. E também dificuldades em certos tipos de coisas. (Aluno)

\section{Desafios no processo de inclusáo educacional do aluno com dupla excepcionalidade}

Com respeito aos principais desafios enfrentados no processo de inclusão do aluno superdotado com transtorno de Asperger na escola regular, sobressaíram-se os seguintes aspectos: (a) a interação social limitada do aluno, (b) a dificuldade emocional apresentada pelo aluno, (c) a assincronia entre o desenvolvimento cognitivo e psicomotor do aluno, (d) a baixa tolerância do aluno em lidar com alteraçóes em sua rotina, e (e) a compreensão literal do aluno nos diversos contextos comunicativos.

Interação social limitada do aluno. Em conformidade com a análise documental empreendida, avaliação psicológica realizada por profissional da sala de recursos de altas habilidades/superdotação constatou que o aluno, em 2011, evidenciava limitaçôes nas interaçóes sociais, o que tornava seu ajustamento grupal difícil e, consequentemente, influenciava sua expressão afetiva. Em 2015, de maneira semelhante, reavaliação psicológica, igualmente conduzida por profissional da sala de recursos de altas habilidades/superdotação, reiterou que, naquele momento, o aluno permanecia apresentando dificuldades no processo de interação social. Consoante a psicóloga, ele manifestava pouca interação com os colegas, já que tinha preferência por realizar seus trabalhos escolares individualmente e por lanchar sozinho ou, às vezes, elegia um único colega para brincar. Entretanto, foi salientado no relatório que caso houvesse algum interesse comum por um determinado assunto, ele conseguia estabelecer relaçóes de parceria com os colegas para o desenvolvimento da atividade proposta. Em 2016, avaliação médica efetuada por médica neurologista infantil sublinhou, mais uma vez, que o aluno demonstrava histórico de dificuldade de relacionamento.

De acordo com os relatos de grande parcela dos participantes do estudo (mãe, professores e do próprio aluno), o aluno apresenta limitações 
de interação social ao longo de seu processo de desenvolvimento. Letras iniciais maiúsculas serão utilizadas para representar o nome dos amigos ou dos colegas de turma citados pelo aluno no decorrer de sua entrevista, tendo em vista a preservação da identidade dos colegas.

O G.D. era uma criança que eu percebi já de imediato que tinha algumas dificuldades de relacionamento. Ele queria sempre estar mais só. $\mathrm{O}$ contato com as outras crianças era pouco. (Professora do aluno no primeiro período da educação infantil)

Ele não tem muitos vínculos com os colegas. Ele só tinha vínculo com um aluno que foi transferido por motivo de saúde da escola. Era o aluno que ele mais se aproximava. (Professor atual do aluno de educação artística)

Porque ele sempre conversava assuntos que náo interessavam às crianças. Ele explicava tudo nos mínimos detalhes. Ele quer explicar e ele demora para explicar. E é isso que as crianças não têm paciência. (Mãe)

Assim, eu tenho amigo. É pouco, mas eu tenho amigos. É, assim, na verdade, tem um grupo que eu fico que é o grupo de quatro amigos que tem que é: o M1, o L., o M2 e o J. (Aluno)

Entretanto, é relevante destacar que, segundo relatos da professora da sala de recursos de altas habilidades/superdotação, da mãe e do próprio aluno, ele consegue relacionar-se com mais facilidade com pessoas mais velhas ou com pares que possuem interesses semelhantes aos seus.

Ele gosta de assunto, tendo assunto do interesse dele ele vai longe. Se o assunto for do interesse dele, ele interage. Entáo, isso para mim é um progresso. Ele interagindo eu posso ir trabalhando e mediando. (Professora atual do aluno da sala de recursos para atendimento educacional especializado aos alunos com altas habilidades/ superdotação)

Ele só faz amizade com os mais calmos, mais sossegados e mais inteligentes. Que tenham alguma coisa em comum com ele. (Mãe) 
Ele não estuda comigo na escola, mas há um tempo a gente se tornou bem amigo que é o P. Ele é um pouquinho mais velho do que eu. Desde quando ele chegava, ele trazia junto muito jogo para a gente jogar, daí, passando disso, a gente foi se tornando amigo mesmo. Assim, o P. ele não é o tipo de pessoa que eu assim gosto realmente, ainda mais que, tipo, ele já está chegando a ser adolescente. Só que o que é bom da gente mesmo é que realmente os tópicos que a gente fala, que a gente tem interesse não são os mesmos, mas é na mesma faixa. (Aluno)

Conforme os professores e a mãe, a mediação da interação social do aluno tem sido favorecida pelas intervençóes pedagógicas propostas pelos docentes em sala de aula e pelo apoio materno no contexto familiar.

Ele, assim, participa das conversas se grupo está falando sobre um assunto x. Esse grupo específico que ele está hoje é um grupo de pré-adolescentes, muitos do $6^{\circ}$ ano. Eles são um grupo mais agitado que tem interesses sobre música. Quando eles estáo falando de música, o G.D. expóe a opinião dele. Então, assim, da forma dele ele interage, o que eu faço é meio que ajustar a organização das falas para que ele possa falar. Porque, assim, se deixar só ele falar, os outros daqui a pouco náo vão ter paciência. (Professora atual do aluno da sala de recursos para atendimento educacional especializado aos alunos com altas habilidades/superdotaçáa)

Então, a gente foi incluindo ele nas brincadeiras para ele ir se adaptando até que deu uma estabilizada. Ele conseguiu terminar o ano já brincando e compartilhando. Ele conversava comigo. Eu tento trazer esses meninos para mais perto de mim. Incluo eles com aqueles que não têm dificuldade para ele estar ali e o outro está sendo espelho. Eu utilizava a estratégia de não excluir ele de nada. (Professora do aluno no primeiro período da educação infantil)

Ele não é de muita proximidade. Ele não gosta de proximidade física. Proximidade física, entáo, jamais. Mas, eu aprendi a respeitar esse limite. No início era mais difícil, eu chegava perto. Mas depois eu fui entendendo o processo dele. Então, hoje, o que eu busco é mais observar ele de longe, tentar não estar muito próximo 
fisicamente porque eu já vi que ele rejeita isso, mas sempre estou verificando até onde ele está indo, até onde ele chegou. (Professor atual do aluno de educação artística)

Eu sempre coloco ele para brincar. Eu levo sempre ele para a casa de amigas. Eu nunca perdi uma festinha de aniversário, porque tem muitas mães que dizem: "Ah, porque ele é Asperger ele não gosta de grito, ele não gosta de barulho". Eu nunca! Eu coloco ele no meio do barulho porque eu acho que a terapia está aí. (Mãe)

No decorrer das observaçóes realizadas no contexto escolar, também foi possível verificar que o aluno possui uma melhor interação social com os pares da sala de recursos de altas habilidades/superdotação do que com aqueles da classe comum do ensino regular. No ambiente da sala de recursos, pode-se dizer que a interação social do aluno com dupla excepcionalidade foi facilitada pelo número reduzido de estudantes na turma (apenas seis) e pelo compartilhamento de interesses comuns com os colegas com altas habilidades/superdotação, ao passo que na classe comum do ensino regular a turma era composta por 28 estudantes com variados níveis de desenvolvimento cognitivo e com características bastante diversificadas. Nesse sentido, é razoável afirmar que houve confluência entre as avaliaçóes realizadas pelos profissionais especializados (médica neurologista infantil e psicólogas), a percepção dos participantes do estudo e as observaçóes promovidas pelas pesquisadoras no contexto escolar acerca da questão de interação social do aluno superdotado com transtorno de Asperger.

Dificuldade emocional apresentada pelo aluno. Segundo a análise documental conduzida, avaliaçáo psicológica realizada por profissional da sala de recursos de altas habilidades/superdotação evidenciou que o aluno, em 2011, demonstrava dificuldade na autorregulação dos impulsos, baixo nível de tolerância à frustração e reações inadequadas. De modo semelhante, de acordo com a percepção da mãe, de dois professores participantes da pesquisa (primeiro período da educação infantil e educação artística) e do próprio aluno, ele apresenta dificuldades emocionais constantes no decorrer seu processo de 
desenvolvimento. Entretanto, é relevante mencionar que, conforme a mãe, o aluno já fez acompanhamento psicológico e que, atualmente, encontra-se na fila de espera para dar continuidade à terapia.

Ele tinha baixa frustração. Fez uma tarefinha e pingou uma cola aqui, já năo queria mais e aí já chorava. Naquele momento eu comecei a ver que ele tinha algumas coisas diferentes nessa questão da rigidez, nessa questão de não querer errar. Se ele fizesse uma letrinha errada, ele se desesperava. (Professora do aluno no primeiro período da educação infantil)

A dificuldade dele pelo que eu percebo, desde o início do ano que eu estou com ele, é uma dificuldade mais, assim, emotiva, muito mais emotiva. Eu acho que essa parte afetiva dele é bem comprometida. Ele mantém muita distância. Mas, o choro melhorou bastante porque no início era bem mais punk. (Professor atual do aluno de educação artística)

Sou uma pessoa um pouco irritada e chorona. Outra coisa também é que eu sou um pouquinho irritado. Primeiro se algo me frustrar demais. Eu náo sou uma pessoa, assim, de querer mal. Uma pessoa violenta. Uma pessoa que briga. (Aluno)

Vale destacar que, durante o período de observaçóes realizado no contexto escolar, foi possível presenciar, durante uma das aulas de Educação Artística, um único momento de dificuldade emocional vivenciado pelo aluno. Ele começou a realizar uma atividade solicitada pelo professor de modo independente, entretanto, em dado momento, não conseguiu acompanhar a produção do trabalho e começou a chorar. Quando o professor percebeu que o aluno estava chorando, sentou-se ao lado dele e auxiliou-o a dar continuidade à tarefa proposta. $\mathrm{O}$ aluno foi acalmando-se gradativamente, contudo, permaneceu chorando de modo mais comedido até o término da aula.

Em contrapartida, no ambiente da sala de recursos de altas habilidades/superdotação, não foi observado nenhum episódio de dificuldade emocional enfrentado pelo estudante, o que também não foi destacado pela professora do referido atendimento em sua entrevista. Dessa 
maneira, pode-se dizer que houve convergência entre a avaliação psicológica realizada por profissional especializado da sala de recursos de altas habilidades/superdotação, a percepção dos participantes do estudo e as observaçóes promovidas pelas pesquisadoras no contexto escolar acerca da questão emocional apresentada pelo aluno com dupla excepcionalidade.

Assincronia entre o desenvolvimento cognitivo e psicomotor do aluno. Em consonância com a análise documental empreendida, a avaliação médica conduzida por médica neurologista infantil ressaltou que o aluno, em 2016, demonstrava inteligência muito superior à média, embora apresentasse dificuldade motora. Da maneira análoga, foi destacado por dois professores (primeiro período da educação infantil e educação artística) e pela mãe, no decorrer de suas entrevistas, que o aluno manifestava assincronia entre seu desenvolvimento cognitivo e psicomotor. Segundo a mãe e o professor de educação artística, o aluno tem evidenciado progressos no que se refere à coordenação motora fina ao longo de sua trajetória escolar, sendo relevante destacar que o apoio materno foi fundamental para o favorecimento da escrita cursiva do aluno.

Ele é muito inteligente. Ele tem tirado boas notas. Eu acho que ele não tem um fino acabamento ainda. A coordenação motora dele fica um pouco a desejar, mas, assim, ele cumpre todas as especificaçôes que o trabalho pede. Ele não pega no lápis normal. Ele escreve com muita força. (Professor atual do aluno de educação artística)

Ele começou a ler antes de 3 anos. A coordenação motora fina dele era bem ruim. A professora não conseguiu, mas comigo você vai conseguir. Colocava ele sentado na mesa lá na minha irmã e vamos treinar a cursiva. E colocava para escrever frases no caderno. Eu mesma colocava as frases e as letras. E fomos treinando, treinando. (Mãe)

Baixa tolerância do aluno em lidar com alteraçôes em sua rotina. De acordo com a análise documental realizada, avaliação psicológica empreendida por profissional da sala de recursos de altas habilidades/ superdotação constatou que o aluno, em 2011, revelava insegurança para enfrentar situaçóes de mudança de rotina diária. Em 2016, avaliação médica efetuada por médica neurologista infantil evidenciou, 
mais uma vez, que o aluno manifestava incômodo com mudanças de rotina. De maneira semelhante, foi salientado pela professora da sala de recursos de altas habilidades/superdotação e pela mãe, no decorrer de suas entrevistas, que o aluno demonstrava baixa tolerância em lidar com alteraçóes em sua rotina diária.

Ele é muito preso à rotina. Ele é tão preso à rotina que ele não tem dificuldade de entender. Assim, ele está fazendo uma atividade x e desperta o meu celular porque é o horário do lanche, se eu falar assim "hora do lanche", ele levanta e vai para o lanche porque ele já sabe que é horário do lanche. (Professora atual do aluno da sala de recursos para atendimento educacional especializado aos alunos com altas habilidades/superdotação)

Tudo dele é no horário certinho. Para sair ele tem que ter horário. Tudo dele é ali no prazo. Se ele tem que ir para a catequese e é 3 horas, 2 e meia ele já está pronto. Tudo dele ele se programa. (Mãe)

Compreensão literal do aluno nos diversos contextos comunicativos. Conforme a análise documental empreendida, a avaliação psicológica realizada por profissional da sala de recursos de altas habilidades/ superdotação ressaltou que o aluno, em 2011, apresentava dificuldade em compreender a perspectiva do outro. Em 2016, avaliação médica conduzida por médica neurologista infantil salientou, mais uma vez, que o aluno manifestava pouca compreensão de pistas sociais. De forma semelhante, o próprio aluno, em sua entrevista, demonstrou que possui dificuldade em compreender a perspectiva das outras pessoas nos diversos contextos comunicativos, já que, geralmente, realiza uma leitura literal da fala de seus interlocutores.

Assim, a minha dificuldade mais, às vezes, é entender algumas coisas porque eu sou um pouquinho lerdo, só para falar. Eu sou meio lerdo porque tipo você vai perguntar uma coisa para mim que, às vezes, eu não entendo o que você fala, mesmo se for algo um pouquinho fácil de fazer e entender, eu não entendo. Eu demoro um pouco para entender porque tem vezes que eu não ouço tão bem as palavras e não ouço as coisas direito. (Aluno) 


\section{Papel desempenhado pela sala de recursos de altas habilidades/ superdotaçáo no favorecimento da inclusáo educacional do aluno com dupla excepcionalidade}

De acordo com a maioria dos participantes do estudo, o atendimento educacional especializado na sala de recursos de altas habilidades/ superdotaçáo favorece o processo de inclusão do aluno com dupla excepcionalidade na classe comum do ensino regular na medida em que impulsiona seu desenvolvimento cognitivo, social e emocional, ao (a) valorizar suas potencialidades, seu talento e suas áreas de interesse; (b) contribuir para o aumento de sua autoestima e de seu autoconhecimento; e (c) desenvolver sua socializaçấo.

Ajuda em muita coisa. Porque o que acontece, a sala já traz essa dinâmica de respeitar a área que ele gosta, a área de interesse. Então, assim, ninguém vai criticá-lo por falar só de cinema. Todo mundo compreende. Então, ele já é aceito. A gente faz muita atividade de autoconhecimento. Quem eu sou, o que eu gosto, o que eu faço bem, o que eu odeio. (Professora atual do aluno da sala de recursos para atendimento educacional especializado aos alunos com altas habilidades/superdotação)

Lá tem o profissional "PhD” nisso, que era o que eu não tinha na época. Então, o profissional mais do que eu ia saber aproveitar mais as potencialidades do G.D., que foi o que aconteceu. (Professora do aluno no primeiro período da educação infantil)

Porque nas altas habilidades ele vai acabar aprimorando essas habilidades, eu acho isso interessante. Esse olhar especializado fortalece porque as altas habilidades, se você vai para um núcleo desses você vai colocar as suas habilidades em prática. Que ele demonstra talento, que ele vai estar se destacando socialmente dos demais naquela área específica, naquela habilidade. Então, eu acho superimportante. (Professor atual do aluno de educação artística)

Se náo fosse a sala de recursos, ele náo manteria uma certa socialização com crianças. $\mathrm{E}$ eu, às vezes, chego bem de pontinha de pé, e mesmo ele mais reservado, às vezes, eu chego, e eu percebo ele num papo com os amigos dele. Com os meninos das altas habilidades ele 
tem um convívio natural. Lá o relacionamento com os colegas é mais fácil do que na escola regular, mesmo com a questão reservada dele. Os interesses dele lá são mais próximos dos outros colegas. (Mãe)

$\mathrm{Na}$ sala de recursos tem muitas pessoas que eu posso comunicar e falar. Não é igual a escola onde só tem umas pessoas que eu não consegui falar e é só isso. Eu não socializo tão, assim, tão direto com outros. Nem me socializo não só porque tem poucas pessoas, mas também porque essas poucas pessoas são interessantes de ter, são interessantes de conhecer e de ver. (Aluno)

Além disso, conforme a gestora da escola regular e dois professores (sala de recursos de altas habilidades e primeiro período da educação infantil), de maneira geral, a troca de informaçóes entre a sala de recursos de altas habilidades/superdotação e a escola regular também favorece o processo de inclusão educacional do aluno superdotado com transtorno de Asperger.

A itinerante vem até a nossa escola. Ela acompanha os alunos. Ela faz esse vínculo direto com a sala de recursos que são os professores que atendem mais de perto esses alunos. Ela passa sempre. Ela também fala com os professores sobre altas habilidades. (Gestora da escola regular)

Então, a psicóloga vai lá. A itinerante vai lá. Explicar não só sobre Asperger, mas também sobre superdotaçáo. E elas vão orientar. E tanto orientam quanto às características, mas elas vão orientar mais na questão das altas habilidades, dele ter altas habilidades e de ter essa dupla excepcionalidade. (Professora atual do aluno da sala de recursos para atendimento educacional especializado aos alunos com altas habilidades/superdotaçáo)

Eu tinha o retorno da mãe e, de vez em quando, também da pessoa que estava com ele lá que era a itinerante. Entáo, a gente tinha sim essa troca. Às vezes, eu falava alguma coisa para a mãe e a mãe passava e vice-versa. Então, a gente tinha esse intercâmbio de informaçóes. (Professora do aluno no primeiro período da educaçáo infantil) 


\section{Discussão}

O presente estudo teve como objetivo analisar o processo de inclusão educacional de um aluno superdotado com transtorno de Asperger no ensino fundamental a partir da perspectiva dos diversos atores envolvidos: gestores, professores, mãe e o próprio aluno. Os resultados da pesquisa indicaram que, de maneira geral, a inclusão do aluno com dupla excepcionalidade na classe comum do ensino regular foi considerada um procedimento bem-sucedido, já que o aluno contou, desde o seu ingresso na educação infantil até o momento da realizaçáo da pesquisa, com uma rede sistematizada de apoio empenhada em potencializar seu desenvolvimento cognitivo, social e emocional. Os dados revelaram ainda que o excelente desempenho acadêmico do aluno e os progressos conquistados por ele no que diz respeito, principalmente, aos aspectos socioemocionais foram determinados por uma confluência positiva de diversos fatores associados tanto ao contexto escolar quanto familiar, o que torna a inclusão educacional do aluno com dupla excepcionalidade um processo de natureza complexa e multidimensional.

É importante salientar que, no contexto escolar pesquisado, a concretização da política pública de educação inclusiva da SEEDF (SEEDF, 2010, 2014) foi responsável por favorecer o processo de inclusão educacional do aluno com dupla excepcionalidade participante deste estudo de caso. Desde o seu ingresso na educação infantil até o momento da realização da pesquisa, o que totaliza um período ininterrupto de oito anos consecutivos, o aluno sempre esteve incluído em classes comuns do ensino regular da SEEDF e também contou com o suporte educacional especializado da sala de recursos de altas habilidades/superdotação, o que lhe proporcionou um ensino diferenciado baseado em suas características e necessidades individuais. Certamente, a adoção de tais medidas educativas contribuiu para: (a) a promoção do seu sucesso acadêmico, (b) o seu melhor ajustamento no contexto escolar, (c) a potencialização de seu desenvolvimento cognitivo, social e emocional, (d) a valorização do seu talento e de suas áreas de interesse, e (e) a melhoria de sua autoestima e de seu autoconhecimento. 
O estudo de caso empreendido por Guimarães (2009) também constatou que a promoção do sucesso escolar de alunos superdotados com transtorno de Asperger encontra-se alicerçada nos seguintes pressupostos: (a) inclusão na classe comum do ensino regular, (b) participação em programas para alunos com altas habilidades/superdotação, e (c) adoção de um currículo flexível. Já a pesquisa proposta por Silveira (2014) evidenciou que, no contexto analisado pela autora, a escola dificultou o processo de inclusão do aluno superdotado com transtorno de Asperger participante de seu estudo, mesmo contando em sua estrutura com o suporte especializado da sala de recursos de altas habilidades/ superdotação, justamente por deixar de oferecer-lhe atividades de diferenciação curricular e de aceleração de conteúdo. Em seus resultados, Silveira (2014) chamou atenção para o fato de que a comunidade escolar atribuiu maior valor às dificuldades do estudante do que às suas potencialidades, o que desencadeou um aumento em seus comportamentos inadequados e de sua rejeição por parte de colegas e professores.

Reitera-se, portanto, a percepção de que a inclusão educacional do aluno com dupla excepcionalidade é um processo de natureza complexa, tendo em vista que a presença isolada de determinados fatores, como, por exemplo, a disponibilização de sala de recursos de altas habilidades/superdotação dissociada de adaptaçóes curriculares e do envolvimento dos diversos atores escolares, não é suficiente para assegurar o êxito da inclusão de indivíduos com tais singularidades na classe comum do ensino regular. Por isso, é relevante que todos os profissionais envolvidos no processo de inclusão do aluno com dupla excepcionalidade (gestores, professores, psicólogos, orientadores educacionais e demais profissionais de apoio) passem a compreender que, por causa de seu desenvolvimento assincrônico, esses estudantes demandam um atendimento educacional que leve em consideração o seu desenvolvimento global, e não apenas as suas possíveis limitações (Baum, 2009; Bianco et al., 2009; Webb et al., 2007).

Constatou-se, com base nos resultados obtidos, que a inclusão educacional do aluno superdotado com transtorno de Asperger participante desta pesquisa foi alicerçada na colaboração de toda a comunidade 
escolar (gestora, professores, profissionais de apoio e familiares), visto que, de forma geral, os diversos atores envolvidos estiveram empenhados em viabilizar ações voltadas à promoção de seu sucesso escolar, do desenvolvimento de seu talento e da diminuição de suas limitaçóes. De acordo com a literatura, é fundamental que todos os seguimentos institucionais estejam verdadeiramente engajados na proposição e no incremento de atitudes coletivas em prol da diminuição das atitudes discriminatórias e do consequente aumento do respeito à diversidade (Kozleski et al., 2015; Muega, 2016; Pimentel \& Nascimento, 2016; Silva \& Leme, 2009).

No que diz respeito à importância da equipe gestora no favorecimento da inclusão dos alunos com necessidades especiais, estudos realizados por Kozleski et al. (2015), Muega (2016), Pimentel e Nascimento (2016) e Silva e Leme (2009) salientam que o gestor da escola regular assume um papel de liderança na construção de uma cultura inclusiva, uma vez que, em âmbito local, ele é responsável por impulsionar o esforço de toda a equipe de trabalho em benefício da inclusão desses alunos. De modo semelhante, os resultados deste estudo de caso igualmente sinalizaram que, no contexto escolar investigado, as iniciativas da gestora possibilitaram o incremento de açôes pedagógicas destinadas ao favorecimento da inclusão dos alunos com necessidades especiais, dentre as quais: (a) a proposição de momentos de formação continuada dos professores em um paradigma inclusivo, em parceria com a SEEDF, por meio de cursos, palestras e capacitaçóes coletivas; e (b) o comprometimento em envolver toda a comunidade escolar em prol da aprendizagem e do desenvolvimento desses estudantes.

Já no que se refere à participação dos docentes, os resultados mostraram que, de forma geral, os professores participantes da pesquisa acreditavam que a viabilizaçáo de uma proposta inclusiva era possível em suas próprias salas de aula, pois contavam com uma boa formação inicial e com suporte institucional adequado para apoiá-los a implementar práticas bem-sucedidas de inclusão educacional em suas salas de aula. De maneira diversa aos resultados encontrados no presente estudo, pesquisas empreendidas por García-Barrera e De La Flor (2016) e Wechsler e Suarez (2016), com relação especificamente à formação 
docente para atendimento aos alunos superdotados, constataram que os professores não são adequadamente preparados para ensinar os alunos com altas habilidades em suas salas de aula. Já os resultados encontrados por Song (2016) sugerem que, geralmente, os docentes que participam de atividades de capacitação acerca da inclusão demonstram atitudes mais positivas em relação à essa temática, o que ratifica a relevância do processo de capacitaçấo docente no estabelecimento de práticas educacionais inclusivas bem-sucedidas.

Vale sublinhar que, de maneira contrária ao que foi apresentado pela literatura, o aluno participante deste estudo teve o privilégio de contar, ao longo de sua vida escolar, com alguns professores que foram capazes de oferecer-lhe, em parceria com a família, as condiçôes adequadas para a promoção de sua aprendizagem e para o favorecimento de suas habilidades superiores. No decorrer desse percurso, sua professora do primeiro período da educação infantil desempenhou importante papel na potencialização de seu desenvolvimento global, visto que ela teve a sensibilidade e a competência de encaminhá-lo, aos 4 anos de idade, para a sala de recursos de altas habilidades/superdotaçáo independentemente de rotulá-lo em virtude de suas dificuldades. Seguramente, o posicionamento da professora esteve pautado na valorização do talento do estudante e na adoçẫo de estratégias pedagógicas que, gradativamente, demonstraram-se oportunas para elevar seu potencial e, consequentemente, minimizar suas possíveis fragilidades, o que encontra respaldo em outras pesquisas empíricas, nacionais e internacionais, que tratam estritamente do aluno superdotado com transtorno de Asperger (Delou, 2013; Guimarães, 2009; Horn, 2012; Johnson, 2010; Lindquist, 2006; Silveira, 2014; Vilarinho-Rezende et al., 2016).

Considera-se, portanto, que a prática pedagógica da referida professora encontra sustentação na concepção defendida por inúmeros autores de que os alunos com dupla excepcionalidade devem ser estimulados a utilizar suas características fortes para compensar suas possíveis dificuldades, pois se suas necessidades educacionais não forem devidamente atendidas eles podem apresentar sentimentos acentuados de fracasso ou frustração em razão da dualidade existente entre 
seu elevado potencial e suas limitações (Baum, 2009; Foley-Nicpon et al., 2011; Guimarães \& Alencar, 2012; Vilarinho-Rezende et al., 2016). No caso específico do aluno superdotado com transtorno de Asperger, foco desta pesquisa, foi possível constatar que, de maneira precoce, tanto a escola quanto a família empenharam-se em proporcionar-lhe experiências educativas destinadas a fortalecer ao máximo o desenvolvimento de seu talento por meio de atividades enriquecedoras e diferenciadas na classe comum do ensino regular, na sala de recursos de altas habilidades/superdotação e no contexto familiar, além de oferecerem-lhe suporte médico, psicológico e pedagógico adequados que foram capazes de minimizar, progressivamente, suas dificuldades socioemocionais, psicomotoras e de comunicação.

No que tange especificamente ao apoio familiar, o envolvimento e a colaboração da mãe foram retratados pela maioria dos participantes como um dos elementos que favorecem tanto a inclusão educacional do aluno quanto o seu desenvolvimento cognitivo e socioemocional. Foi possível notar que a mãe do aluno participante deste estudo de caso sempre esteve empenhada em garantir-lhe, tanto na família quanto na escola, o acesso aos meios que pudessem impulsionar seu desenvolvimento, quais sejam: (a) atendimento precoce na sala de recursos de altas habilidades/superdotação; (b) suporte especializado médico, educacional e psicológico; (c) apoio às demandas socioemocionais do filho; (d) identificação precoce das características de superdotação na criança; e (e) valorização da habilidade acima da média do filho. De maneira convergente aos resultados obtidos neste estudo, Chagas e Fleith (2011) reforçaram em seus resultados de pesquisa, com adolescentes com altas habilidades, que o suporte familiar pode ser considerado como um dos fatores de maior impacto no desenvolvimento do talento.

Com base nos resultados obtidos neste estudo, pode-se concluir que a parceria estabelecida entre a equipe escolar e a família propiciaram ao aluno superdotado com transtorno de Asperger, foco desta pesquisa, uma rede de apoio sistematicamente organizada que se revelou efetivamente competente para atendê-lo tanto na potencialização de suas habilidades quanto na superação de suas limitaçóes. Isso contribuiu 
para a promoção da sua inclusão educacional na classe comum do ensino regular ao longo de toda a sua escolarização e para o fortalecimento de sua autoestima. Tal constatação pode ser reforçada com base na boa percepção que o próprio aluno possui com relação a si mesmo e às suas habilidades, o que indica a consolidação de um autoconceito positivo que foi construído a partir das características ambientais favoráveis que estiveram ao seu redor. Portanto, conforme Delou (2007), é importante reafirmar que, em tempos de políticas públicas inclusivas voltadas ao respeito às diferenças, a parceria estabelecida entre a escola e a família desempenha um papel preponderante na promoção do desenvolvimento do talento humano e na valorização da diversidade.

Como limitaçóes deste estudo, podem ser apontados os seguintes aspectos: (a) a impossibilidade de generalização dos resultados obtidos para a população de alunos superdotados com transtorno de Aspeger incluídos em classes comuns do ensino regular da educação básica, (b) a incapacidade das pesquisadoras em entrevistar todos os professores atuais do aluno, e (c) a dificuldade das pesquisadoras em observar o processo de inclusão educacional do aluno durante as aulas de todas as disciplinas dos anos finais do ensino fundamental. Entretanto, destaca-se que a pesquisa realizada foi capaz de analisar o processo de inclusão educacional do aluno com dupla excepcionalidade de maneira detalhada e profunda pelo fato de ter utilizado diversas fontes de informação (entrevistas, análise documental e observaçóes) para a coleta de dados. Além disso, foi possível entrevistar a primeira professora do aluno na educação infantil, o que contribuiu para elucidar a trajetória de desenvolvimento do aluno desde o seu ingresso no contexto escolar aos 4 anos de idade. Investigar o processo de inclusão educacional de alunos com quaisquer tipos de dupla excepcionalidade a partir da perspectiva dos diversos atores envolvidos, tais como, gestores, professores, familiares, colegas e dos próprios alunos, bem como averiguar o processo de inclusão educacional do aluno superdotado com transtorno de Asperger em outras etapas da educação básica e na educação superior são sugestóes para futuras pesquisas. 


\section{Referências}

American Psychiatric Association. (2014). Manual diagnóstico e estatístico de transtornos mentais: DSM - 5 (5a Ed.). Porto Alegre, RS: Artmed.

Arizaga, M. P. G., Conejeros-Solar, M. L., Rodríguez, K. S., \& Solís S. A. (2016). Doble excepcionalidad: análisis exploratorio de experiencias y autoimagen en estudiantes chilenos. Revista de Psicologia 34(1), 5-37. https://doi.org/10.18800/psico.201601.001 Assembleia Geral da Organização das Naçóes Unidas. (1948). Declaração Universal dos Direitos Humanos. Paris, França: ONU.

Barbosa, A. J. G., Rosini, D. C., \& Pereira, A. A. (2007). Atitudes parentais em relação à educação inclusiva. Revista Brasileira de Educação Especial 13(3), 447-458. https://doi.org/10.1590/ S1413-65382007000300010

Bardin, L. (1977). Análise de conteúdo. Lisboa, Portugal: Edições 70.

Baum, S. M. (2009). Talent Centered Model for twice exceptional students. In J. S. Renzulli, E. J. Gubbins, K. S. McMillen, R. D. Eckert, \& C. A. Little (Eds.), Systems and models for developing programs for the gifted and talent (2nd ed., pp. 17-48). Mansfield Center, CT: Creative Learning Press.

Besnoy, K. D., Swoszowski, N. C., Newman J. L., Floyd, A., Jones, P., \& Byrne, C. (2015). The advocacy experiences of parents of elementary age, twice-exceptional children. Gifted Child Quarterly 59(2), 108-123. https://doi.org/10.1177/0016986215569275

Bianco, M., Carothers, D. E., \& Smiley, L. R. (2009). Gifted students with Asperger syndrome: Strategies for strength-based programming. Intervention in School and Clinic 44(4), 206-215. https://doi.org/10.1177/1053451208328827

Chagas, J. F., \& Fleith, D. S. (2011). Perfil de adolescentes talentosos e estratégias para o seu desenvolvimento. Psicologia: Teoria e Pesquisa 27(4), 385-392. https://doi.org/10.1590/ S0102-37722011000400001 
Delou, C. M. C. (2007). O papel da família no desenvolvimento de altas habilidades e talentos. In D. S. Fleith \& E. M. L. S. Alencar (Eds.), Desenvolvimento de talentos e altas habilidades: Orientaçôes a pais e professores (pp. 131-141). Porto Alegre, RS: Artmed. Delou, C. M. C. (2013). Transtorno de Asperger com altas habilidades/ superdotação: A dupla excepcionalidade no ensino superior. In E. M. L. S. Alencar \& D. S. Fleith (Eds.), Superdotados: trajetórias de desenvolvimento e realizaçóes (pp. 95-107). Curitiba, PR: Juruá.

Foley-Nicpon, M., Allmon, A., Sieck, B., \& Stinson, R. D. (2011). Empirical investigation of twice-exceptionality: Where have we been and where are we going? Gifted Child Quarterly, 55(1), 1-15. https://doi.org/10.1177/0016986210382575

Foley-Nicpon, M., Assouline, S. G., \& Colangelo, N. (2013). Twice-exceptional learners: Who needs to know what? Gifted Child Quarterly, 57(3), 169-180. https://doi. org/10.1177/0016986213490021

García-Barrera, A., \& De La Flor, P. (2016). Percepción del profesorado español sobre el alumnado com altas capacidades. Estudios Pedagógicos 42(2), 129-149. https://doi.org/10.4067/ S0718-07052016000200008

Guimarães, T. G. (2009). Estudo de caso de um aluno superdotado com Transtorno de Asperger: Desenvolvimento, características cognitivas e socioemocionais (Dissertação de mestrado não publicada). Universidade Católica de Brasília, Brasília.

Guimarães, T. G., \& Alencar, E. M. L. S. (2012). Dupla excepcionalidade superdotação e transtorno de Asperger: Contribuiçóes teóricas. Revista Amazônica, 10(3), 95-108. Retrieved from file://C:/Users/Usuario/Downloads/Dialnetduplaexcepcionalidadesuperdotacaoetranstornodeaspe-4047470\%20(1).pdf

Granemann, J. L., \& Gricoli, J. A. G. (2011). Educação inclusiva: Revisitando práticas e trajetórias na escola. Interfaces da Educação 2(5), 131-139. https://doi.org/10.26514/inter.v2i5.598 
Horn, B. S. (2012). Educating gifted students with asperger's syndrome: A case study of three students and their classroom experiences (Tese de doutorado não publicada). University of Central Florida, Florida, Estados Unidos.

Jonhson, R. A. (2010). A portrait of being artistically talented with Asperger's syndrome: A retrospective case study (Tese de doutorado não publicada). University of Indiana, Indiana, Estados Unidos.

Kozleski, E. B., Yu, T., Satter, A. L., Francis, G. L., \& Haines, S. J. (2015). A never ending journey: Inclusive education is a principle of practice, not an end game. Research and Practice for Persons with Severe Disabilities 40(3), 211-226. https://doi. org/10.1177/1540796915600717

Lindquist, C. L. (2006). The twice-exceptional student identified with Asperger syndrome and giftedness: A qualitative case study (Tese de doutorado não publicada). University of Northern Colorado, Colorado, Estados Unidos.

Ministério da Educação. (2008). Política Nacional de Educação Especial na Perspectiva da Educação Inclusiva. Brasília, DF: SEESP/MEC.

Muega, M. A. (2016). Inclusive education in the Philippines: Through the eyes of teachers, administrators, and parents of children with special needs. Social Science Diliman, 12(1), 5-28. Retrieved from http://www.journals.upd.edu.ph/index.php/ socialsciencediliman/article/view/5230/4700

Neihart, M. (2000). Gifted children with Asperger's Syndrome. Gifted Child Quarterly, 44(4), 222-230. https://doi. org/10.1177/001698620004400403

Ng, S. J., Hill, M. F., \& Rawlinson, C. (2016). Hidden in plain sight: The experiences of three twice-exceptional students during their transfer to high school. Gifted Child Quarterly, 60(4), 296-311. https://doi.org/10.1177/0016986216656257

Ourofino, V. T. A. T. (2007). Altas habilidades e hiperatividade: A dupla excepcionalidade. In D. S. Fleith \& E. M. L. S. Alencar (Eds.), Desenvolvimento de talentos e altas habilidades: Orientaçôes a pais e professores (pp. 51-66). Porto Alegre, RS: Artmed. 
Park, S., Foley-Nicpon, M., Choate, A., \& Bolenbaugh, M. (2018). Nothing fits exactly: Experiences of asian american parents of twice-exceptional children. Gifted Child Quarterly, 62(3), 306-319. https://doi.org/10.1177/0016986218758442

Pimentel, S. C., \& Nascimento, L. J. (2016). A construção da cultura inclusiva na escola regular: Uma ação articulada pela equipe gestora. EccoS Revista Cientifica, 39, 111-114. https://doi. org/10.5585/eccos.n39.3841

Rubenstein, L. D., Schelling, N., Wilczynski, M., \& Hooks, E. N. (2015). Lived experiences of parents of gifted students with autism spectrum disorder: The struggle to find appropriate educational experiences. Gifted Child Quarterly, 59(4), 283-298 https://doi.org/10.1177/0016986215592193

Secretaria de Estado de Educação do Distrito Federal. (2010). Orientação pedagógica: Educação especial. Brasília, DF: Subsecretaria de Gestão Pedagógica e Inclusão Educacional.

Secretaria de Estado de Educação do Distrito Federal. (2014). Referenciais para atuação do serviço especializado de apoio à aprendizagem. Brasília, DF: Subsecretaria de Educação Básica.

Silva, C. L., \& Leme, M. I. S. (2009). O papel do diretor escolar na implantação de uma cultura educacional inclusiva. Psicologia: Ciência e Profissão 29(3), 494-511. https://doi.org/10.1590/ S1414-98932009000300006

Silveira, S. T. (2014). A aprendizagem de uma criança com altas habilidades/superdotação e transtorno de Asperger (Dissertação de mestrado não publicada). Universidade Federal de Santa Maria, Santa Maria.

Song, J. (2016). Inclusive Education in Japan and Korea: Japanese and korean teachers' self-efficacy and atitudes towards inclusive education. Journal of Research in Special Educational Needs, 16(1), 643-648. https://doi.org/10.1111/1471-3802.12324

Teixeira, R., Fernandes, S., \& Bernardes, G. (2016). A educação especial na rede pública de educação em uma cidade do centro-oeste brasileiro. Revista Lusófona de Educação, 33, 179-195. 
Vilarinho-Rezende, D., Fleith, D. S., \& Alencar, E. M. L. S. (2016). Desafios no diagnóstico da dupla excepcionalidade: Um estudo de caso. Revista de Psicología, 34(1), 61-84. https://doi. org/10.18800/psico.201601.003

Webb, J. T., Gore, J. L., Amend, E. R., \& De Vries, A. R. (2007). A parent's guide to gift children. Scottsdale, AZ: Grest Potential Press.

Wechsler, S. M., \& Suarez, J. T. (2016). Percepção de professores em cursos de formação sobre talentos/superdotação. Revista de Psicología, 34(1), 39-60. https://doi.org/10.18800/psico.201601.002 Willard-Holt, C., Weber, J., Morrison, K. L., \& Horgan, J. (2013). Twice-exceptional learner's perspectives on effective learning strategies. Gifted Child Quartely, 57(4), 247-262. https://doi. org/10.1177/0016986213501076

Wright, T. V. (2016). Gifted with Asperger's syndrome (twice-exceptional): The difference post-graduate certifications held make on early childhood teachers' knowledge (Tese de doutorado não publicada). Liberty University, Virginia, Estados Unidos.

World Health Organization. (2018). International classification of diseases (11th revision). Retrieved from https://www.icd.who. int/icd/entity/437815624

Zagona, A. L, Kurth, J.A., \& MacFarland, S. Z. C. (2017). Teachers' views of their preparation for inclusive education and collaboration. Teacher Education and Special Education, 40(3), 163-178. https://doi.org/10.1177/0888406417692969 